\section{THE ROLE OF THE STATE}

Philipp Engelkamp, a co-founder of the renewable-energy start-up firm Ineratec in Karlsruhe, says that public funding was crucial when he and his partners were trying to get their business off the ground. Ineratec's product - a compact chemical reactor that can convert waste gases into liquid fuels and other chemicals - is based on decades of research at the Karlsruhe Institute of Technology.

Engelkamp and his co-founders applied for funding with the help of the Karlsruhe Institute, where several of the founders were based. Ineratec secured funding to help make its research commercially viable, including more than $€ 1$ million in grants for equipment and stipends for the founders, sourced from funds at the state and federal level.

One of Ineratec's key funders was EXIST, one of the country's most prestigious incubators. Since 2006, the programme has given out over $€ 500$ million to more than 2,000 projects.

The money is channelled through universities and comes in the form of either a business start-up grant to support researchers for a limited time as they work to launch companies or as a transfer of research grant of $€ 1$ million on average for translating more expensive, highrisk projects into commercially viable products.

Other funding schemes include state-level programmes. Berlin, for example, offers a sixmonth stipend to teams who leave the German capital's research institutions to start a firm. And many states offer similar support to entrepreneurs emerging from their university systems, such as the Junge Innovatoren ('Young Innovators') programme in Baden-Württemberg, which Engelkamp and his partners tapped when they were starting Ineratec.

\section{BRINGING IN BUSINESS SENSE}

Another key element of EXIST and many other funding programmes is an emphasis on teams and training. The groups that are successful in their funding applications often feature team members with a Master of Business Administration (MBA) or equivalent experience in addition to members with a research background.

Bringing in business talent is essential, because the majority of German researchers lack industry experience. "Most researchers have never had the experience of working at a company, let alone running one," says Jasper Emeis, a business-school graduate who is working with Schmitt to get Grown Valve off the ground. "They're totally overwhelmed by the business part."

For researchers looking to spin their research into start-up gold, conditions in Germany have never been better - but that doesn't mean Germany is the best fit for every business. Medicaltechnology start-up firms have to contend with
Germany's stringent regulatory system and privacy laws. For example, Langemak says a longstanding ban on treating patients remotely has made things tough for telemedicine-oriented startups, and companies in the health space have to first win over German insurers, as most patients are used to being fully covered. (Germany's doctor's association recommended lifting the ban last year.)

And there's a lingering cultural bias against researchers commercializing their own work. "Many medical doctors and researchers want to be entrepreneurs, but don't feel comfortable with the way business is done," says Langemak, who trained as a doctor before earning an MBA. "They struggle to communicate why this is a great product."

Steffen Terberl, head of the Profund Innovation office at the Free University of Berlin, admits that more experienced researchers have traditionally seen spin-offs as a distraction. "They are often afraid that their fundamental research would suffer," he notes.

\section{OPEN TO THE WORLD}

Terberl says that at universities in Berlin and elsewhere in Germany, an influx of researchers from abroad - particularly from countries with a long tradition of bench-to-business translation efforts, such as the United Kingdom, Israel and the United States - is helping to change that academic culture.

And the start-up scene itself is as open to scientists from abroad as the university system. Nationality, entrepreneurs say, is no barrier when it comes to accessing funding or working in the start-up scene. Take Clue, a menstruationtracking app founded in Berlin in 2012 by Ida Tin, a Danish entrepreneur. As the app has grown to encompass more than 10 million active users, Tin has recruited researchers from around the world to relocate and work at the company. "Germany has pretty generous visa laws, and that's crucial for us," Tin says. "It's a good place to attract and retain talent."

There's a flip side to generous public support, however. Engelkamp and Langemak say that German researchers are often too concerned with perfecting their product and are not comfortable with the 'fail fast' ethos that is prevalent among their US counterparts.

German investors, too, are less eager to make big bets. Banks and venture-capital funds need to be won over, often through a painstaking, months-long due-diligence process. However, Engelkamp says that this is not a substantial problem: "You can find money in Germany, and we have. But this 'moonshooting' vision of growing very big and not caring about the initial investment is missing." -

Andrew Curry is a journalist in Berlin.

\section{CASE STUDY MARKUS DAHLEM}

No more career headaches.

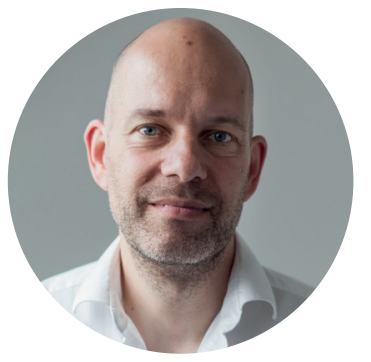

The iPhone didn't even exist when Markus Dahlem wrote his first business plan in 2004. But the migraine researcher still thought that there might be a market for predictive algorithms that could help migraine sufferers to tame their crippling headaches.

Dahlem, a theoretical physicist by training, wound up shelving the idea. However, by 2015 , his academic career had stalled.

That's when he got a call asking whether he'd be interested in working on a migraine-tracking start-up firm. "I didn't think about staying in academia for a split second. Nowadays, it's a start-up that can change the world and have an impact on society," he says. "With the advent of digital health, I felt like it was the right time to start with the app."

He left his guest-researcher position at the Humboldt University of Berlin to co-found Newsenselab, the Berlin-based company behind the $\mathrm{M}$-sense migraine-tracking app. He and his co-founders were awarded a business start-up grant to help them get off the ground. The stipend helped Dahlem to support his family while getting the app into shape. "That soft transition was needed for me as an academic," Dahlem says. "My co-founders were 15 years younger and single, but I had my family to pay for."

Newsenselab has since received two rounds of seed funding. Dahlem still lives in Berlin, close to his former colleagues and research network. "At the end of the day, it's more about what you want," Dahlem says. A.C. 